\title{
BLOOD VOLUME AND CAPACITANCE VESSEL COMPLIANCE IN THE QUADRAPLEGIC PATIENT
}

\author{
J.W. Desmond, M.B., B.S., F.R.C.P.(C) AND A.K. LAWS, M.B., F.F.A.R.C.S., F.R.C.P.(c)
}

THE NATURE of functional changes occurring in chronic quadraplegic patients and the mechanisms responsible for the altered responses to stress situations, which occur in these patients, are not yet clearly defined and understood. Anaesthesia and surgery are examples of stress situations in which these patients respond in abnormal fashion, and instability of the circulation during surgery has been of concern to anaesthetists. ${ }^{1-4}$. These patients often experience precipitous falls in blood pressure as a response to exceedingly small doses of anaesthetic agents.

We have investigated the total blood volume and the compliance of the capacitance vessels of the circulation in the upper limb in a group of such patients, in an endeavour to define some of the altered responses in the chronic quadraplegic, which might account for this troublesome fall in blood pressure and which might point the way to some measures of control to improve the risk of anaesthesia and operation in these patients. ${ }^{5}$

\section{Method and Materials}

A group of 27 quadraplegic patients was chosen at random for this study.

Blood volumes were measured in all cases using $\mathrm{I}^{131}$ albumen (RISA) and the "Volumetron". (The calculation was based on the weight of the patient at the time of the current admission to hospital.

Again on a random selection basis, seven patients had upper limb plethysmography. Capacitance vessel compliance of the forearm was determined with a Whitney mercury-in-rubber gauge. Normal vessel compliance was first recorded. A mild stress was then applied, through the use of a Bird respirator set in the assist/control position, and triggered by the patient. ${ }^{6.8} \mathrm{~A}$ positive pressure sufficient to cause alteration in venous return was added, and again the limb vessel compliance was recorded. No changes in compliance could be recorded in any of the patients studied.

The anaesthetist who haphazardly injects a large dose of thiopentone into this type of patient during induction might be doing him a great disservice, by dilating a resistance and capacitance system which has no means of retaliating against this aggression. We have observed many times under such conditions that blood pressures which start at normal levels may soon fall to levels at which cerebral, coronary and renal function cannot be maintained.

Department of Anaesthesia, University of Toronto, and Toronto General Hospital, 


\section{Discussion}

The literature contains many references to the frequency and severity of hypertension during anaesthesia in the paraplegic patient, and much stress has been placed on the role of autonomic hyper-reflexia ${ }^{2-7}$ and the occurrence of both hypertension and hypotension resulting from this phenomenon. In 1970, one of the present authors described in some detail the problems relating to anaesthesia in the paraplegic, ${ }^{1}$ and in that discussion it was surmized in agreement with other writers on the subject that there might be a reduction of blood volume in these patients. We have now documented this in a small group of quadraplegic patients. Now that we know this to be true in many cases, the question arises as to whether all quadraplegics should have a blood volume measurement prior to surgery.

Failure of the capacitance side of the circulation to respond in normal fashion to the application of a respiratory stress ${ }^{8}$ is due, we suggest, to disordered control of the autonomic receptors in this system, associated with the quadraplegia, with the result that the capacitance system is abnormally dilated. This failure of compliance of the capacitance side of the circulation increases the serious implications and importance of the reduction in blood volume which we have documented.

Further reference to Table I indicates that in many of these patients the phenomenon of automatic hyper-reflexia was recorded at some stage of the surgical management and nothing was done about this. Many patients had recorded systolic blood pressures of 60 to $70 \mathrm{~mm} \mathrm{Hg}$ for the major part of the operation. In reviewing the case records of these patients, it is interesting that all seemed to develop fever of $43.9^{\circ}$ to $44.4^{\circ} \mathrm{C}$ on the first or second day post-operatively, despite prophylactic antibiotic therapy. Jousse ${ }^{9.10 .11}$ states that elevation of temperature in these patients is conducive to pressure sores and poor wound healing.

Finally we note that in many of those who had low blood volume, the red cell volume was disproportionally reduced in relation to plasma and total blood volume. The question which eventually must be faced is whether such changes disrupt wound healing and increase the morbidity in these patients. Such effects on wound healing and morbidity are suggested by the following two case reports:

\section{Case Reports}

Case 1. A 34-year-old male patient involved in a high-jump accident ten years ago, presented for surgery in December, 1971. The greater trochanter was excised and a rotation graft brought over the excised area. As there was very little blood loss, no blood was given to him during the operation. His blood pressure during operation never got above $70 \mathrm{~mm} \mathrm{Hg}$ systolic, in spite of administration of three litres of lactated Ringer's solution. It remained at this level through his stay in the recovery room and during the next three weeks his condition remained unsatisfactory. His graft broke down and at this stage we did a blood volume measurement on him. It was grossly deficient, with a red cell volume of $1020 \mathrm{ml}$. His physician was immediately informed and four pints of blood were transfused. A dramatic change occurred within twenty-four hours. He has since had several uneventful anaesthetics. 


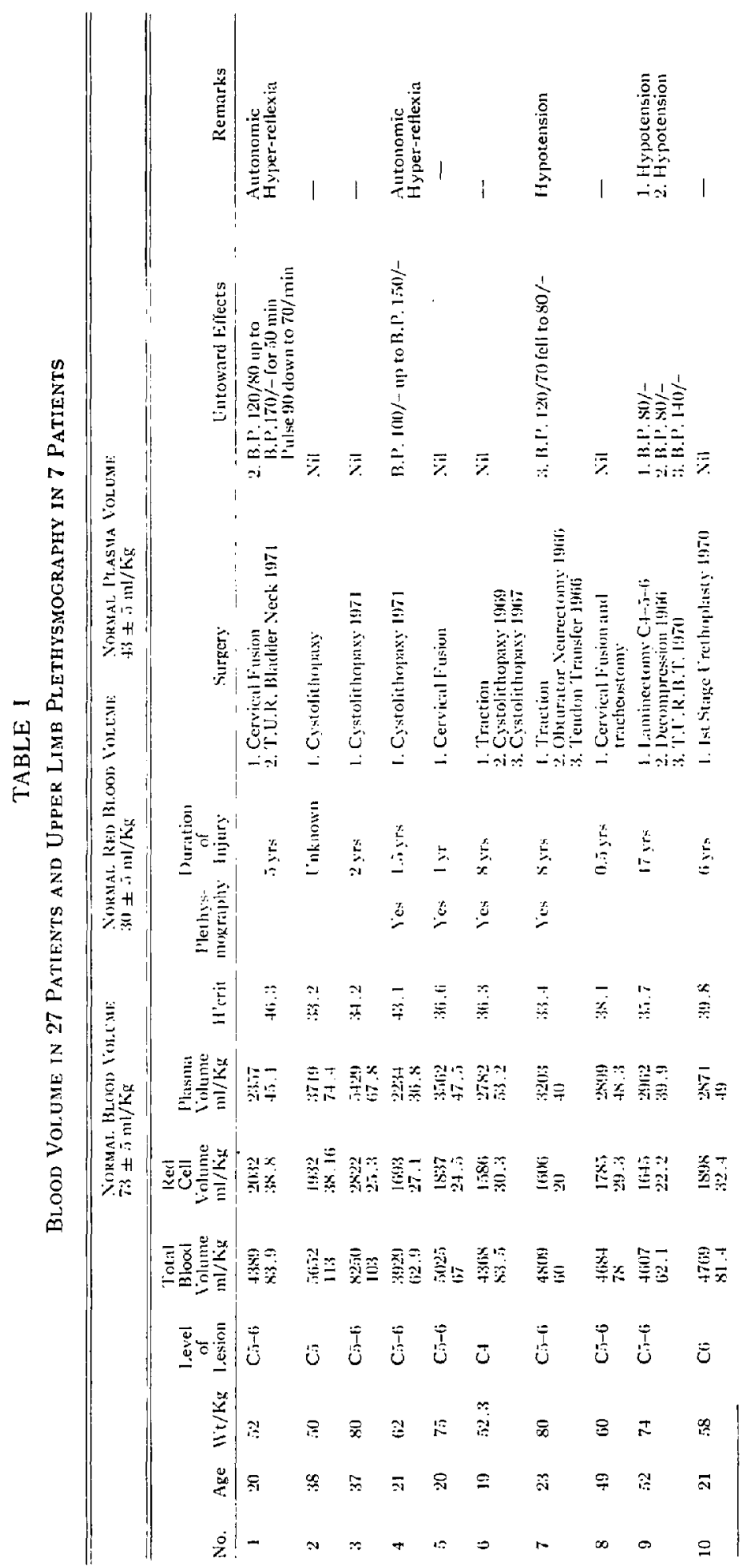



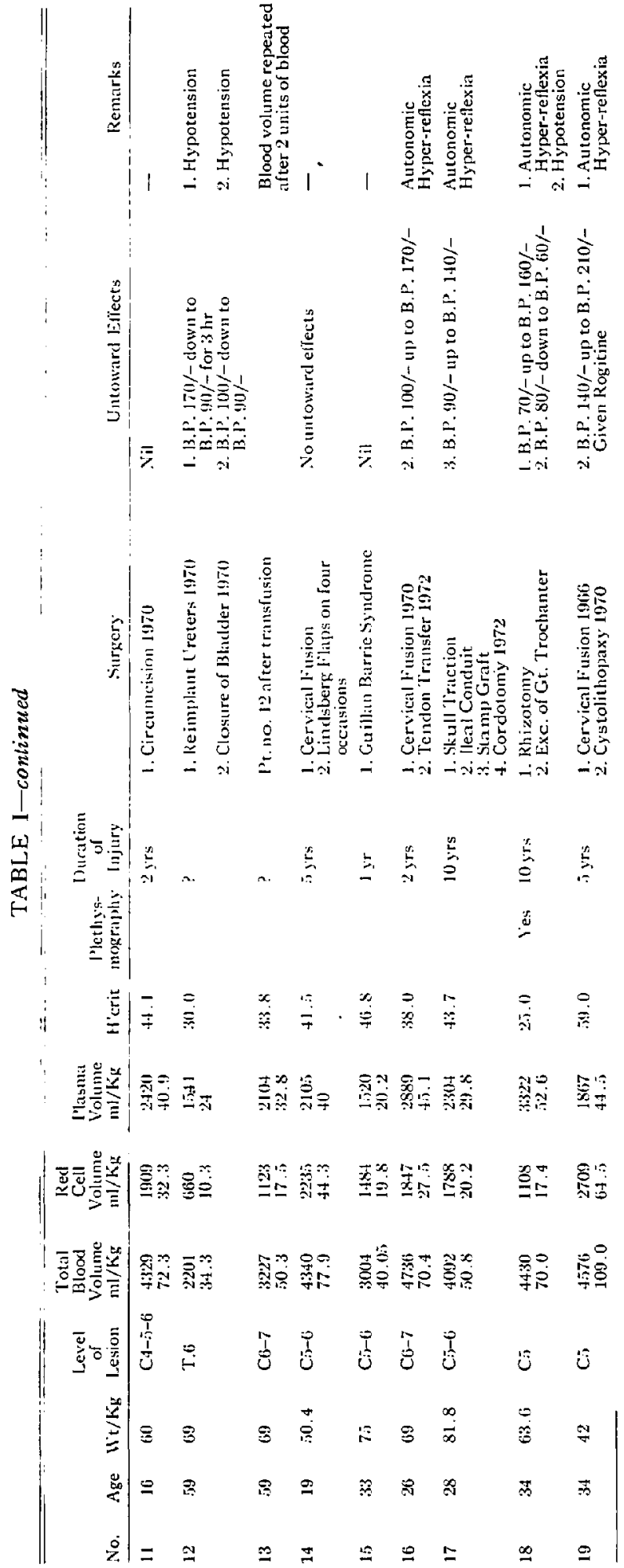


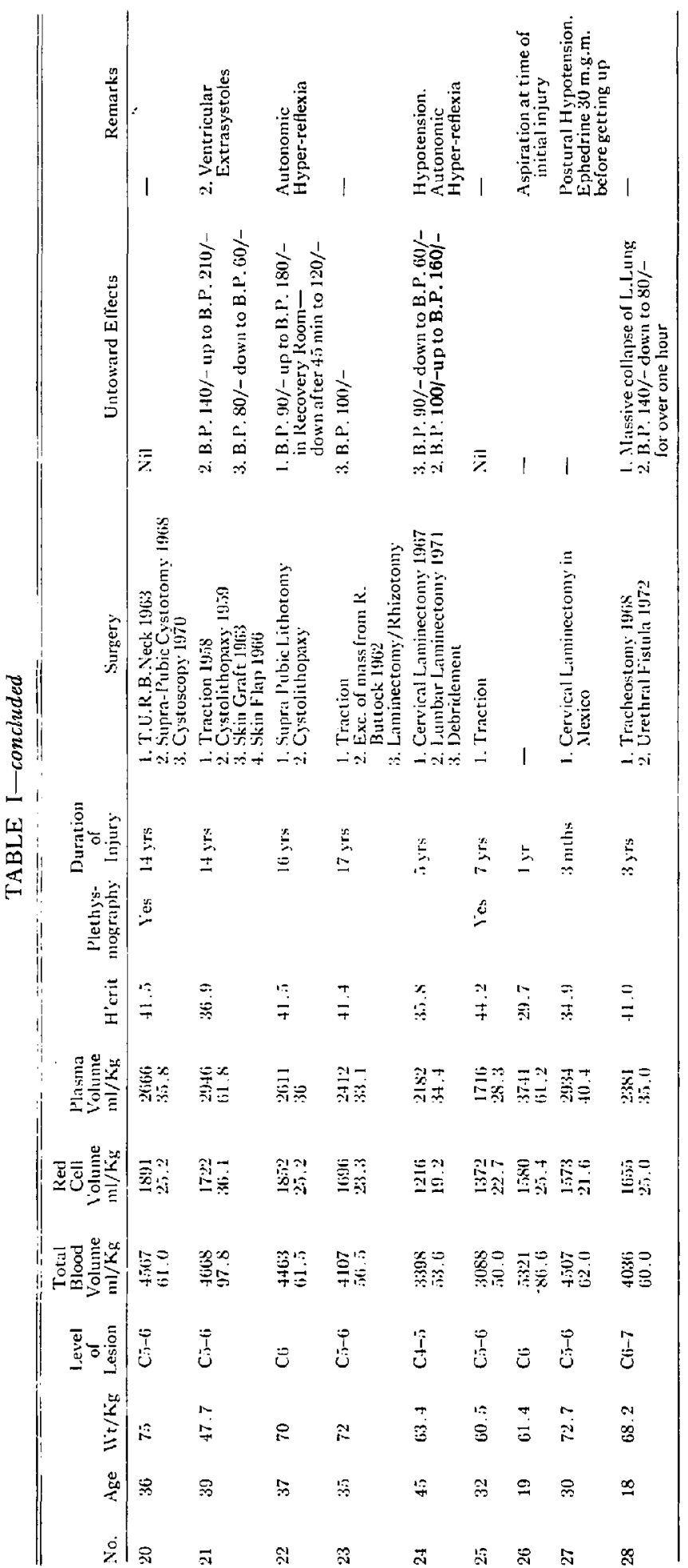


Case 2. The patient became a quadraplegic following a cervical laminectomy in 1969. During 1971-72 he had several grafting and debridement procedures with poor results. Systolic blood pressures during operation were occasionally recorded at $60 / \mathrm{mm} \mathrm{Hg}$. A blood volume determination on this patient showed a low total volume and a very low red cell volume $(1216 \mathrm{ml})(19 \mathrm{ml} / \mathrm{kg})$. These abnormalities were corrected and the patient showed a remarkable change in his general attitude to life and his physical reaotion to surgery and anaesthesia were subsequently good.

\section{SUMMARY}

A study of 27 quadraplegic patients selected at random has demonstrated that both blood volume and vessel response to stress are unpredictable. A study of the surgical history of quadraplegic patients suggests that wound healing is impaired and that morbidity is increased in such patients unless the blood volume is replaced to near normal. Blood volume measurements should be routine in the pre-operative assessment of these patients.

\section{RÉSUMÉ}

Une étude de 27 patients quadriplégiques choisis au hazard, a démontré que le volume sanguin et les vaisseaux répondent au stress de façon imprévisible. Une étude portant sur l'histoire chirurgicale des quadriplégiques, suggère que la guérison des plaies est retardée et que la morbidité est augmentée chez ces patients, à moins que le volume sanguin ne soit corrigé à des chiffres quasi-normaux. De routine, la mesure du volume sanguin devrait faire partie de l'évaluation préopératoire chez ces patients.

\section{REFERENCES}

1. Dessond, J. Paraplegia: Problems confronting the anesthesiologist. C.A.S.J. 17: 435-45I (1970).

2. Kurnick, N.B. Autonomic hyperreflexia and its control in patients with spinal cord lesions. Am. Int. Medicine 44: 678-686 (1956).

3. Bors, E. \& French, J.D. Management of paroxysmal hypertension following injuries to cervical and upper thoracic segments of the spinal cord. Arch. Surgery 64: 803-812 (1952).

4. Rocc, A. \& VAndai, L. Problems in anaesthesia for paraplegics. Anesthesiology 20:348 (1959).

5. Geisler, W.O. \& Jousse, A.T. Management of the spinal injured patient. Modern Medicine $23: 19$ (1968).

6. Ernsting, I. The effect of raised intrapulmonary pressure upon the distensibility of the vessels of the upper limb. J. of Physiology 137: 52 (1957).

7. Giliberti, B.J., Goldfein, J., \& Rovernstein, E.A. Hypertension during anaesthesia in patients with spinal cord injuries. Anesthesiology 15: 273-279 (1954).

8. Warson, W.E. Vascular distensibility of the hand during pressure breathing. British Journal of Anaesthesia 33: 600-605 (1961).

9. Jousse, A. Personal communication (1971).

10. Lougheed, W.M., Gillies, B., \& Rankin, H. Paraplegia care in Canada (1969). Modern Medicine 25: 17 (1970).

11. RoBson, C.J. Personal communication. 